\title{
The State and Education during the Commonwealth
}

W 1 . ARTHUR F. LEACH wrote in the Contemporary Retiew for asked to whom our system of secondary education was mainly due, and who was the founder of most of the grammar schools on which it chiefly rests, he would answer, without hesitation, Edward VI.' In the course of a brilliant article Mr. Leach shows how entirely unfounded on fact is the reputation of Edward VI, and eventually styles the youthful king 'spoiler of schools,' not restorer of them. Mr. Leach's contention that the educational impulse which resulted in the growth of English schools was not due to Edward VI may be extended, as he himself hints, to Henry VIII. In fact, it is not too much to say that the royal personal foundations of Henry VIII, Edward VI, and Elizabeth put together are insignificant in comparison with their confiscations.

Daring the time of the Tudors we had in England the revival of learning and the reformation of religion. The reformation of education is always the last wave on the tide of culture, and naturally, therefore, came a generation or two later. I cannot now trace the educational wave from the point of view of the literature of the subject. I shall in this article attempt to show the movement in the practical domain. This impulse towards the 'reformation' of schools, parallel in some degree to that of religion, can be traced-in the treatment of educational literature-through the period 1600-1640, but appears in its fall vigour in the age of Cromwell, 1640-1660. This conclusion, founded upon a study of the educational literatare of the period, is curiously confirmed by a reference to the statistics of school foundations. I quote from the elaborate and painstaking inquiry of Mr. Horace Mann, the American educationist, in that most comprehensive educstionsl census which he made for the English government in 1851. The number of schools founded between 1501 and 1601 (i.e. including a portion of the reign of Henry VII, with the whole of those of Henry VIU, Edward VI, Mary, and within two years of the whole of that of Elizabeth) was 185. That was the work of a century, and included the whole of the endowed schools of royal, corporate, and private founders. Between 1601 and 1651, i.e. within the next half-century, 
there were 186 endowed schools founded. That is to say, the period ending with the age of Cromwell shows an activity of school-founding on an arerage twice as vigorous as that of the Tudore. I agree, therefore, with Mr. Leach in rejecting the common tradition of the intensity of the school-foundation impulse as being greatest with Edward VI, but I wish further to emphasise the indications of exceptional educational energy as evident in the first half of the seventeenth centary, particularly in the age of Cromwell.

School-founding is not the only sign of educational life. It is curious that the first government grants of the nineteenth century. given from the treasury in 1832 to elementary schools were for bricks and mortar, and that it took yeare to roach the philosophy of Mrs. Browning, that it 'takes a soul to move a body,' by providing any educational standard as to the sort of teaching and of teachers in grant-aided schools. Between 1640 and 1660 there was abroad a desire to reconsider the educational problems, and to consider them not only from the point of view of bricks and mortar, but also as to the work and functions of the school in the community, and the educational ends which should be kept before the schools. There was a spirit of enthusiasm as to the teacher's work-the recognition that teaching was a noble task. How clearly the desirability, nay, the necessity, of considering as of first importance the qualification and proportion of the teachers is realised by Samuel Hartlib, for instance, will be at once noticed from such a passage as the following :-

The training up of scholars in one school or two, though very great and most exact, reformed, will be but an inconsiderable matter in respeet of a whole nation, and have no great influence upon the youth thereof, where so many schools remsin unreformed and propagate corruptions; therefore the propagation of reformed schools is mainly aimed at; and to that effect the training up of reformed schoolmasters is one of the chief parts of this design ... And the schoolmaster in a well-ordered commonwealth is no less considerable than either the minister (of religion) or the magistrate, becanse neither the one nor the other will prosper or subsist long without him.

Hartlib enunciates this principle in a preface to the 'Reformed School,' by John Dury, which must have been written by 1650 , for in that year John Dury put forth his 'Reformed Library Keeper" in continuation of the 'Reformed School.' Dury, after receiving a letter of approbation and appreciation from Hartlib of the ' Reformed School,' writes, 'I would be more glad if God would open it a way for us to put it in practice.'

Education was recognised as a matter of national concern by James Harrington in his 'Oceana.' Free schools, he says, ought to exist, 'erected and endowed to a sufficient proportion' for the children of the people. They should, for the sake of continuity in 
removing from one to another, be governed 'by the strict inspection of the censors of the tribes.' Education ought to be compulsory. Parents of one son may educate him as they think well, and at their own expense, but a parent of two or more sons may send his sons to school gratis, till fifteen. Harrington, indeed, suggests that education should be, as we say, free, universal, and compulsory. It should, perhaps, be noted that he does not explicitly include girls in the scheme.

It is not necessary to dwell long upon so well known a work as John Milton's tractate 'Of Education.' ' Fie speaks of the reforming of education as one of the grestest and noblest designs that can be thought on, and, thanks to Hartlib's 'entreaties' and ' conjurements,' we have Milton's opinions on the subject. But the reason I refer to them at all in this connexion is that Milton conceived that he was writing something eminently practical, and suggested these more or less localised university colleges of $\mathbf{1 5 0}$ etudents should be planted up and down the country. After the pattern proposed there should be 'as many edifices as may be converted to this use as shall be needful in every city throughout this land.' Similarly John Hall, in his 'Humble Motion to Parliament,' arged the reformation of the universities as the first desideratum, pointing out that the universities ought to be providing not only the absorbers of scholastic learning but also the dispensers of 'real' knowledge, so that the 'ways of education should be made smooth and children with a pleasant success be possessed of all the treasures of real knowledge ere they could have thought they had entered the gates.' What could have been more significant for educational progress if national education should have become organised, under the direction of men bent upon the culture and training of the teacher as a directly recognised and as the first consideration?

This is what nearly happened in England in 1641. Parliament in that year invited the great Comening, ${ }^{2}$ the father of educational method, to visit England, with a view apparently to his taking an active share in assisting and directing Hartlib in the promotion of the educational reform of England. It is, indeed,

1 See also Milton's Ready and Easy Way to establish a Free Commonwealth, in Prase Works, iii. 427. 'They should havo here [i.e. in England] also schools and academie日 at their own choice, wherein their children may be bred up in their own sight to all learning and noble edacation; not in grammar only, but in all liberal arto and services, This would soon spread much more knowledge and civility-yea, religionthrough all parts of the land, by communicating. the natural heat of government and cultare more distributively to all extreme parts, which now lie numb and neglected, would soon make the whole nation more industrious, more ingenious at home; more potent, more honourable abroad. To this a free commonwealth will easily assent (nay, the parliament hath had already some such thing in design), for of all parlisments a commonwealth aims most to make the people flourishing, virtuous, noblo, snd high-spirited.'

For a fall account of this visit see Masson's Brilton, iii. 199-215. 
uncertain with what reform he was to have been entrusted, and over what area he was to have had direction. But from the general characteristics of Comenius it is clear that he would not have been satisfied with any system of reforms of a less drastic nature than those suggested by Dury and Hartlib. It is worth pointing out, too, that rarely has a great edacational reformer had such a sympathetio and capable lieutenant as Comenius had in Hartlib for reducing noble and far-reaching reforms to practice. Judging from the writings of Comenius, Dary, and Hartlib, judging from their clear perception and hearty enthusiasm for the social movement of the time, there can be no doubt that England was on the verge of an organisation of elementary, if not of secondary, education.

The triumvirate of Comenius, who visited England in the winter of 1641-2, Dary, and Hartlib was capable of great things educationally. Comeniug's visit to England was in the year of the struggle over the Remonstrance, 1641. In that year ${ }^{3}$ the house of commons resolved, on Hyde's report,

that all deans, deans and chapters, archdeacons, prebendaries, chapters, canong and petty canons, and their officers shall be utterly abolished and taken away out of the church; and secondly, that all the lands taken by this bill from deans and chapters shall be employed for the advancement of learning and piety, provision being had and made that his majesty be no loser in his rents, firstfruits, and other duties, and a competent maintenance shall be mede to the several persons concerned, if such persons appear not pecoant and delinquent to the house.

Here, then, were revenues voted directly for the 'advancement of learning and piety, and the three friends Hartlib, Dury, and Comenius, tres juncti in uno-Hartlib, the most enterprising man of his age; ${ }^{4}$ Dury, the most conciliatory ${ }^{5}$ and Comenius, the most keen-sighted educationist in Europe ${ }^{6}$-ready to organise: That parliament would have supported three such authorities, and smoothed the way towards a settlement of the reformation of schools, there is a strong presumption. But the moment of opportunity was lost by the outbreak of the civil war. Comenius withdrew from England, and by the time of the end of the civil. war other more pressing needs for the large revenues appropriated as confiscated from the church were too obvious to be overlooked in favour of edacation.

As to the amount of the revenues confiscated from the deans and chapters, it appears that a sum of not less than 2,000,000l. of capital value was disposed of for purposes of state, fitting out an

- Journal of House of Commons, Jane 15, 1641, ii. 176.

- Bee Masson's account of Hartlib, Life of Milton, iii. 215-81.

- Bee Dictionary of National Biogr. Ivi. 261-3, article 'Darie John.'

- Bee B. B. Laurio'в Lifo of Comonius. 
Irish expedition, \&c. Over and above this there was an annual income of 50,000l. or 60,000l. administered between 1643 and 1650 by the Committee for Plundered Ministers, and between 1651 and 1658 by the trustees for the maintenance of ministers. It will thus appear that the resolution of the commons devoting the revenues from the confiscated ecclesiastical property to the 'advancement of learning and piety' went for the most part to 'piety' only; but not without a protest. Of course many of the ministers made conspicnous advocacy of the importance of 'learning' and a 'learned ministry,' and the conjunction of 'learning and piety 'in the ministers may have seemed to many not only a justification of the devolution of the revenues entirely to them without regard to the laity, but there are the clearest indications that, in the minds of the more progressive, universal education of children was included in the ides of the advancement of learning. and the 'reformation.' It is essential to prove this point, because it is incontestable that if it be the fact that there was a distinct demand from the more democratic side, as well as from the educationists of the period, then to the Commonwealth is to be ascribed the origin of that social and religious impulse which has only in our own day found national satisfaction, after a delay of two hundred years.

In the British Museum ${ }^{7}$ is a remarkable broadside entitled 'A Good Motion.' It is dated 14 Jan. 1646, but is anonymous. It shows what was the popular interpretation of the house of commons' resolation, viz. the encouragement of the 'learning' not only of those who already had had a good grammar school educetion, but of those poorer children for whom there were no available schools.

If the rich (this document begins) will desle their Bread to the Hungry, Isaiah 58, 7, by forbearing one Meal's Meat in a week, ${ }^{8}$ and foring the value of it but for one year to maintain the children of the poor; and the poor do the like to maintain their owne children, the rich may be re-imbursed in one year.

The method proposed is to borrow $400,000 l$. on the 'assurance' of the bishops' temporalities, and to devote the 'whole revenue of the bishops' temporalities to breed ap children in learning.' More then this :

A glorious university may be founded in London, every Bishop's House in the counties be employed as Eton Colloge, victuals become cheaper; epiritual and corporal famine be avoided. And all these (in reason) be cartainly effected without expense of one halfpenny.

The writer pointe out that

- Pressmark, 669, 1. 10/108.

- Referring to the 'weekly mesl,' the ralue of which was paid to the defonce of Inonion. 
the value of one meal in a week in each Parish (one with another) smounteth but to twenty shillings (there being almost 10,000 parishes in England), and ten thousand pound weekly amounteth to five handred thousand pounds in one year; then in one year the four hundred thousand pounds will be re-imbarsed with an over-plus, and God, the Bich, the Poor (yes all) be well pleased.

This curious, acute, and philanthropic appeal seems to me to sound the note of popular educational interest and energy which we are accustomed to suppose first showed itself in England about 1832. This paper of 1646 is suggestive of an 'education-mad' set, for all the world like that of Brougham and his associates. The paper quoted is issued in London, but in other portions of the country people were awakening to an educational problem. I will instance two cases, that of Lincoln and that of Gloucestershire.

In the 'Perfect Diurnall' of 26 March 1649 is given the - Humble Address of the free and wel-affected People and Inhabitants of the County and City of Lincoln.' This was sent to Lord Fairfax and the general council of war. The following is a copy of clause 9 of that address:- -

That some Publio Schools for the better education and principling of youth in virtue and justice, wonld soberly be considered of and settled, that so by not leaving them look to themselves and their careless Parents (the Laws being deficient to instruct them well when children, though not to punish them for it when men) they may not remain liable to be scourged for the faults of their natural and civil Parents rather than their own, as they now do. Besides that, according to the structure this generation propounds to build for the next, it may not again incline to fall by its ow $\mathrm{n}$ weight, through negligence of timely preparing fit materials to support and confirm it.

No words could express more neatly the modern arguments on which the interference of the state with education is founded than the lines italicised.

'Gloucestershire's Desire' is the second title to the 'Vox Populi,' to which Samuel Harmar gives expression in 1642. The declared object of his small book is the "setting up of schoolmasters in every parish throughout the land generally.' Nothing could be more remarkable than the clearness with which he announces his object on his title-page, except perhaps the almost universal neglect he has received. ${ }^{9}$ Harmar's pamphlet takes the form of a petition to parliament, and urges the necessity of the education of all children in a parish, 'as well the poor as the rich.' At least reading, writing, and the principles of religion should be taught to every child-the very subjects, it may be noted, which became

- I have gritten more fally on Harmar in an article in the Educational Rovicw. June 1894, from which I have here borrowed. 
the curriculum of the charity schools which arose like mushrooms about the end of the seventeenth century, the first having been built before $1685 . .^{10}$ Harmar has very clearly in his mind the joining of 'religion and piety.' Ministers of religion complain that so little can be done in the way of training their flocks. Harmar suggests that this poorness of spiritual harvest is largely due to the lack of a school education.

Harmar's main argument is the one which had so much weight in the earlier portion of the present century, viz. that the early days of youth spent idly are a source of mischief and danger to the community. Harmar's words are vigorous, and I quote them not only on that account, but also because they seem to me inevitably to suggest the introdaction of compulsory school attendance.

This idle life (he says) at length leadeth poor children either to become beggars or thieves; and this is one cause why countries and cities are so opprest with beggars in many places at this present; and if it happen that these idle persons cannot get their living by begging, they will adventare to steal, and so do much hurt many years to many of the king's subjects before they be taken; and all this mischief to the Land in general doth greatly arise from the first cause, which is the want of a Bchoolmaster in every Parish.

Harmar makes the suggestion (startling to find in 1642), Why should not the law allow a 'rate on men's estates for the teaching of young children,' as well as for relieving the poor?

From the London broadside of 1646 , the city of Lincoln address of 1649, and Samuel Harmar's 'Gloucestershire's Desire,' there can be no doubt of the widespread feeling urging towards a national system. That this was a hope in which the educationists joined goes without saying, but for the purpose of strengthening the claim of the Commonwealth to be regarded as the period when the modern tide of the democratisation of education set in I will only briefly illustrate further from Samuel Hartlib and Charles Hoole, though other educationists of the period might also well be added.

Samuel Hartlib's 'London's Charity Inlarged ' (1650) is an earnest appeal to 'still the orphan's cry,' to grant money (the sum named is 1,000l.) towards 'work for the employment of the poor and education of poor children, who many of them are destroyed in their youth for want of being under a good government and education.' Hartlib calculates that 100 children can have three meals a day, and the officers of a school and workhouse can be obtained for 120l. - of which the schoolmaster is to have 20l., with lodgingthe total expense for teaching and feeding altogether he puts at

10 See William Blake's Silver Drops, or Serious Thoughts, 1685, giving an account of his aharity school for 'near 40 poor or fatherless ohildren born all at or near High. gate, Hornsey, Haimpstead.' 
461l. 5s., but calculates that the 100 children can earn 260l. 58. The total outlay he puts at 201l. 5s., and for 500 children, therefore, roughly, $1,000 l$. ' We conclude,' he says, ' if the 'City of London should lose 1,000l. per annum in this work, yet they would gain by it, in the preservation of 500 children and more ; for if children are not kept under a government they will in time grow to a generation of ungodly wretches . . . and so become a burden to the Commonwealth.' Evidently Hartlib is proposing what we cail an industrial school, but his argument is the modern one of education as a preventive of crime.

In the remarkable preface or 'Advertisement' to the translation of Cato's ' Distichs,' published in 1659, Charles Hoole replies to certain critics charging him with the prostitution of learning: 'I have wondered to hear that some of our profession should blame others for going about by those means to prostitute learning and to make the way of knowledge too common a thing, which,' adds Hoole, ' in my judgment is impossible.'

I have now spoken of the projects and aspirations of the Commonwealth period, in matters concerning the education of youth, and of the remarbable opportunity jast before the outbreak of the civil war for a 'settlement of the reformation of schools' and their propagation.

It may at once be said that the assumption that Cromwell's government had any ill-will against the universities and schools, or attempted to damage them, is entirely opposed to the facts. For example, the act for the sale of the deans and chapters' lands was specially exempted from applying to any college or house of learning. Moreover, 2,000l. per annum was ordered to be employed for the increase of maintenance of the mastership of colleges. Commissioners were appointed by ordinance for 'visiting' the universities, and also for visiting the schools of Westminster, Winchester, Merchant Taylors, and Eton. (Scobell, 2 Sept. 1654). In the act for the sale of the deans and chapters' lands is the express section: 'That all and singalar the revenues, rents, issues, fees, profits,' \&c., whatsoever which before 1 Dec. 1641 'have been and then ought to be paid, disposed, and allowed unto and for the maintenance of any grammar school or scholars . . . shall be and continue to be paid as they were before the said 1 Dec. 1641, anything in this present act notwithstanding.'

Such a proviso required a strong hand to secure its effectual carrying out. There is a remonstrance of the commissioners for charitable uses in Middlesex to the Protector, given in the "Calendar of State Papers,' 31 July 1655. It is interesting as showing the difficulties with which Cromwell had to contend in dealing with educational matters. But there is no sign, notwithstanding the 
urgency of the commissioners, that Cromwell gave the slightest response in their direction.

It is one of our many mercies that, while you converse with lings and great ones abrosd, you note the condition of poor Lazarus at home, and order us to find a way for relief of the afflicted poor; but onr hands are tied by the fllth of corruption in the administration of charitable ases, and the fountain so dammed up that languishing sonls are tantalised by the near approach of a remedy of which they cannot reach the least drop.

You have given ample powers to the county commissioners to reform abuses, on the act of 48 Eliz., but they are checked by a proviso in the act that it is not to extand to towns, colleges, hospitals, or schools where there are specisl governors appointed by the founders to govern lands, \&c., left for charities, and this proviso is the plea of the grand delinquents. We beg its removal, as being contrary to law, and striking at the heart of the act, exempting all special governors and visitors from appeals; it is also against equity, but this was not understood by the house before its passing.

We beg you to use the legislative power, which resides wholly in you during the interval of parliament, and either pass an additional ordinsnce qualifging this proviso, or, if this be deemed too high a demand, an expedient of less noise would be to constitute the commissioners in this employment specisal visitors, governors, and overseers pro tem. in their respective jurisdictions, reserving the profits to the ordinary incumbents.

What now did the council of the Commonwealth actually do for education? We might expect a priori that the state would be favourably disposed towards educstion in England, considering that the council in 1658 made a grant of $1,200 l$., the whole of which was to go to the Scotch schools, ${ }^{10}$ and in the same year occur the following allowances to schools in Piedmont:-

To the chief schoolmaster of the valley . . . $20 l$.

To the ten ander-schoolmasters of the valleys . . $6 l$.

And to the three under-schoolmasters in Peross Valley $8 l$. per annum . . . • • . . • . 89l.11

Finding such grants to schoolmasters. in Scotland (the grant to the Piedmontese has, it mnst be confessed, a political rather than an educational significance), it would be surprising if English

10 Cal. State Papers, Domestio Beries, $4 \mathrm{Meg}$ 1658. Declaration by the Protector : - Pinding it a duty not only to have the Gospel set ap, but schools for children erected and maintenance provided therefor ... We and our connoil, desiring that the people mey be instructed in the knowledge of God, their children educated, and vice euppressed, have appropriated 1,200l a yeer to be proportioned by our country in Scotland to these purposes.'

"The other items to professional men are: To John Leger, the chief minister, for expenses in entertaining those who come to him on basiness, 100l.; to Mr. Le Prenx, gratuity, 40l.; to esch of the eight ministers in Duke's dominion, 40l. per annnn; to esch of the three ministers of Val Peross, 10h. per annum: total to ministers, 850l. To stadents in divinity and physic, 40l.; to a phyoician and surgeon, 85l. (Cal. State Papers, Dom. Series, 18 May 1658). 
education were entirely neglected by the council. Without attempting a comprehensive statement of the connexion of the state with education in the period, I hope to illustrate the relations in several directions, and to offer sufficient evidence to show that the recent historians of elementary education in England (e.g. Sir Henry Craik in his 'State Education' 12) are not absolutely correct in giving the impression that the first grant to elementary education in England was made in 1832.

The Case of Grimston.-I choose this illustration because the details are fairly clearly given. Here is the account in the 'Calendar of State Papers,' 26 June 1656 :-

There are in or near Grimstone 100 families, half of them nnsble to read, and within four miles thirty other villages without a schoolmaster; whereupon twenty yesrs ago some well disposed persons erected a school, and endowed it with $5 l$. or $6 l$. a year ; but through these distracted times no addition has been made, as was hoped for, so that the school-house is fallen into decay, the master gone, and error and malignancy like to flow in upon them. But, that learning may not be altogether discountenanced, these persons have now provided a well-affected sohoolmaster, an M.A., and intend to repair the school. Beg an angmentation for the school, which will oblige them to double their devotion and prayers for his.long and prosperous life.

Five signatures are added, with a certificate by Thomas Toll, and seven other justices of peace near, that Grimston is poor but populous; that a small house and two or three acres of land have lately been given for a schoolmaster, and that Edward Bmith, who has been provided, is fit for the place and well affected, with eight signatures. Then follows

Order in Council: To recommend the trustees for ministers to settle 80l. \& year on the Grimston sohoolmasters. Approved June 27.

In comparing such an order of council with the education grant of 1832, it is worth noticing that the latter had reference only to aids to school-building, whereas this of 1656 is to the maintenance of a tercher.

The Case of Prollheli.-This illustrates the conncil of state acting as charity commissioners. Report is made by referees as to Bottwonnog free grammar school, county Carnarvon,

that the bishop of Bangor in 1616 devised a house to maintain the school to be erected at his charge, the schoolmaster to have 201 . a year; that it was built by his executors, but in open fields, a mile from any house, and inconvenient for lodging and diet of the scholars, Pwllheli, the nearest town, being five miles off, and that for two years no school has been kept. Ordered that the trustees dispose as well as they can of the present school-

12 Bir Henry Craik traces the history of 'The State and Edacation' to the date of the ' First ' annual grants. He does not mention the Commonwealth. 
house or its materials, and build one in Pwllheli, with a master's house, and apply to its maintenance the funds left for the school at Bottwonneg. Approved 12 May.

To tarn from schoolhouses to schoolmasters. In illustrating the following cases of inquiries by the major-generals, I do not wish to suggest that their granting permission to certain persons to continue to teach implies any encouragement on the part of the state to education. Of course the significance of their action is simply that, in these cases, the state does not regard the persons named as politically dangerous. Yet even these instances have their importance as illustrating state interference with teachers, as teachers. This is of especial interest in the case of granting licenses to teach. For in the older order of things licenses to teach had come from the church, through the bishops in each diocese. Under the Commonwealth the power vests in the state through the commissioners. Their concern undoubtedly was that the teachers should be well affected to the council. The modern claim for the registration of teachers is precisely that the state should undertake control, only that it should be based not upon political but upon pedagogical soundness.

One of the typical cases of atate interference is in the matter of licenses to teach.

Case of Rob. Mossom.-Petition to the Protector referred to the council of state: 24 Jan. 1655. ${ }^{\text {'s }}$ 'I was sequestered in 1650 for reading the Book of Common Prayer, bat for no other delinquency or scandal, and applied to the teaching of scholars, which I performed diligently and peaceably; I never acted against government. Yet by your late declaration I am prohibited teaching, and deprived of a livelihood for my wife and six small children. I beg a license to teach.' Order thereon ( $24 \mathrm{Jan}$.) in council that the major-general and county commissioners inquire into the case and report, and meantime that Mossom have leave to attend his school, the late orders notwithstanding. Approved 6 Feb.

The 'late declaration' was that of 31 Oct. 1655, following the instructions to the county commissioners, in which royalist clergy were forbidden to teach, requiring that 'scandalous, ignorant, and inefficient ministers and schoolmasters shall be ejected, and how.' Commissioners were appointed, with power to act, in each of the counties of England. Any five of these commissioners, sitting as a court, might examine witnesses on oath as to the insufficiency of any minister or schoolmaster. The accused had the right of answer, but if unsatisfactory the minister or schoolmaster was to be ejected and his stipend or profits sequestered. The commissioners had the power of giving certificates to those who were to be considered qualified. This power was certainly exercised, and occurs in such forms as the following :- 
24 Jan. 1685. Ordered that the major-general of London inquire concerning George Freebonne's qualifications (as schoolmaster) and report, and that meantime he attend his school without interruption, the late orders of council notwithstanding. ${ }^{14}$

Or again-

Francis Neves, a sequestered minister, for leave to continue his vocation of keeping a private school at Lambeth, promising to live honestly. Gives a certificate from the commissioners of Surrey.

Next I quote a curious case of a fellor of a college desirous to be certified as a village preacher and schoolmaster :

Order to the major-general and the commissioners of county Berishirc: His bighness and council having considered the petition and certificate of Henry Chamberlayne, some time fellow of Oriel College, Oxford, and of Shillingford, county Berkshire [where he is preacher and schoolmaster], request you to let him continue in these offices if you find him properly qualified, or otherwise to certify. ${ }^{15}$

Besides ejecting 'insufficient' schoolmasters, 'certifying' and 'granting licenses' to efficient schoolmasters. through an organised body of commissioners throughout England, the council of state, in one instance at any rate, sanctioned and recognised the petition of Noah Bridges (18 June 1653) 'to print, bind, publish, and dispose of a treatise by him set forth concerning arithmetic, provided the book be of his own making.' But state interference went to further lengths even than those of granting licenses, sanctioning books, confirming or ejecting schoolmasters in the villages. The council commissioned at any rate one man to finish a school or text book. There is, unfortunately, no evidence that Fitzpayne Fisher finished the work, nor that it would have been of much value if he had. Still it is worth while to quote the passage as professedly an encouragement to a writer for educational purposes.

Order, on the petition of Fitzpayne Fisher, referred by council, stating his pains in finishing a treatise which will be of great' use in all schools for youth, and intending a journey to Scotland, desires money for it and a pass, to request council to order him the pass and $100 l$., to be paid by Mr. Frost, for his encouragement to perfect the work. ${ }^{16}$

I have thus shown that the state interfered with school buildings, helping in the building in the first instance and maintenance afterwards, and in the licensing and control of the registration of masters, and assumed the direction, in. some.cases, of the management of the public schools as well as the elementary schools. But perhaps

14 Calendar of State Papers, 1655-6, p. 186.

1. Ibid. p. 228. 
the entry of most significance in the minutes of the council of state is at the same time the vaguest: 7 Sept. 1650, 'When the propositions for reforming schools are presented the council will give them all possible furtherance.' Unfortunately there is no further record of these 'propositions.'

There is, however, an interesting minute in the 'Journals of the House of Commons,' vii. 'p. 287; for Wednesdny, 20 July' 1653 : 'Resolved, that a committee be appointed for advancement of learning, and receiving all propositions tending thereunto.' The committee was actually constituted as follows, viz.: Mr. Strickland, Mr. Sadler, Mr. Lawrence, Mr. Wingfield, Dr. Goddard, Colonel Barton, Mr. Spence, Sir Anth. Ashley Cooper, Colonel Sidenham, Alderman Titchborne, Colonel Mountagu, Mr. Lockart, Sir Robert King, Colonel Blunt, to whom were afterwards added Sir Wm. Roberts, Mr. John St. Nicholas, Col. Matthews, Capt. Cust. These were all to meet on Thursday, 21 July 1653, in the Duchy Chamber in the afternoon at two of the clock. The quorum was to be five, and it was referred to the committee of the army to prepare a bill containing such powers as are necessary to be given to that committeo.

But state direction and control, according to the modern doctrine, only justify themselves through state grants of money towards maintenance. There remains for me to give instances of grants made during the Commonwealth. On 12 June 1656 a petition of the inhabitants of Huntingdon, Cromwell's own town, is received, and is referred by the council of state to the trustees for the maintenance of ministers, to consider an augmentation of $80 l$. to the minister, and $40 \mathrm{l}$. to $\mathrm{Mr}$. Taylor, the schoolmaster. From such an entry it will be seen that the sequestered property administered by the 'trustees for the maintenance of ministers' was available for grants to schoolmasters. The term 'ministers,' it is worth noting, includes schoolmasters. Scobell, whose collection of acts and ordinances of the Commonwealth bears date 1658, thus inderes the word:

Ministers $\left\{\begin{array}{l}\text { Preachers. } \\ \text { Schoolmasters. }\end{array}\right.$

It is probably through the inclusiveness of this term that the relations of the state to schoolmasters in the time of the Commonwealth have been overlooked.

Mr. W. A. Shaw, in his introduction to the 'Minates of the Committee for the Relief of Plundered Ministers for Lanceshire and Cheshire,' in the Record Society of those connties (1893), hrs given a remarkable and comprehensive view of the procedure of the committees dealing with the confiscated revenues. He has, so to say, struck the balance-sheet of the whole of the transactions. The 
object he had in hand was the investigation of the relations of the state with the church. It is perfectly clear that the religious test (and the political test), to use our modern phraseology, must have been en essential factor in the dealings of the state with the schoolmasters. Mr. Shaw has been good enough to inform me that the manuscripts containing the accounts, now to be found dispersed at the British Museum, Cambridge, the Bodleian Library, the Record Office, Sion College, and Lambeth, have frequent references to grants to schoolmasters, though the overwhelming number of entries are to preaching ministers. He would be inclined to pat the proportion not less than twenty to one. It must be borne in mind that many of the ministers combined the functions of preaching and teaching school. I have not perused the 'Augmentation Books' stating the separate grants, but I may point out that the odd cases which I have culled from the 'Calendar of State Papers' are there repeated, with variations, over and over again.

...11].. f...

Mr. Shat has supplied me with a typical example from his notebooks. ${ }^{17}$

The Case of Chester Free School.-26 July 1655. Order of the trastees for the maintenance of ministers for the payment of $80 l$. a year out of tonths arising within the county of Derby for the poor scholars of the free school of Chester.

From a further entry it is gathered that twenty-four poor scholars received between them the above sum of $80 l$.

18 Dec. 1650. Whereas by an ordinance of the parlisment of 1 October 1846 an additional maintenance of 86l. a year is granted out of the revenues of the dean and chapter of Chester to the hesd schoolmaster of the free sohool within the city of Chester, and $\theta l$. per annum is by the said ordinance granted to the usher of the said school, to whom these become due by 24 June $1650, \ldots$

Then follows the order for payment of the amounts due. The headmaster was Mr. Greenhalgh, and the usher Mr. John Pack. The order is signed by five 'trustees,' who are members of parliament, the funds administered being managed by a parliamentary committee of trustees. Mr. Greenhalgh's salary before angmentation was 22l., and that of his usher, Mr. Pack, was 10l. They were thus raised to $58 l$. and $19 l$ per annum respectively. It may be added that on 12 July 1655 there was a particular order issued specifying different sources of income to provide for the $\mathbf{8 6 l}$. of angmentation settled on the master of Chester Free School, e.g. rents and tithes of fishing, tithe of Dee Mills $5 l$. issuing out of (i.e. charge upon) vicarage of Eastham 1l.18s. $4 d$, and so on, making 
up the full amount of $36 l$., and replacing the old source of the tenths from Derbyshire, ${ }^{14}$ which bad probably in their turn found another use. This change of source of income is interesting because it shows that the object of helping the maintenance of the school was a more permanent one than that of continuance of the. original source of the grant.

The subject is capable of development, and is highly deservingof study. It is however, I trust, even in this casual form, interesting and suggestive. I have shown that it is inaccurate to speak of the grants of 1832 as the first state aid to education. But I hope I have given reason for thinking that the age of the Commonwealth had not only a partially open pocket for education, but included wise heads and warm hearts among the leaders. It was an age when the educational ideas of the three great men Havtlib, Dury, and Comenius just missed consideration through untoward circumstances and more urgent immediate interests. But never had the educational impulse been so deep and warm. The money grante were readily given, but they did not reach the original idea embodied in the resolution of 1641. The confiscated funds from the deans and chapters of England were deroted, in by far the lion's share of the plunder, to 'piety ' rather than 'learning.' The state direction of education was, when on the verge of initiation, lost in the confusion, and left aside for a couple of centuries.

With such a record as I have all too inadequately sketched it will at least be recognised that some of the glory and repute formerly attaching to Edward VI and his father as the founders of schools, a glory and repute now trampled under the feet of Mr. Leach, might be transferred to Hartlib, Durs, und Comenus, and some share perchance not unduly to Cromwell and his coadjutors, as active friends of educational progress. Remembering the amount and quality of educational literature, the aspirations centred in educational projects and practice, it does not seem inappropriate to compare the educational movement of the age of Cromwell as parallel in direction with the English reformation of religion and the revival of learning. It was with them in aim. Its results, however, were not those of successful practical realisation. But they were the beginnings of the modern spirit. in the democratisation of education. ${ }^{19}$

Foster Watson.

\footnotetext{
1* These counties, Cheshire, Derbyshire, and another county, were taken together for purposes of administration by the trustees.

1- The writer desires to express his gratitude to Mr. C. H. Firth for suggestions. which have materially improred the statement and strengthened the illustrations, of this article.
} 